\title{
Broom Snakeweed Control with Tebuthiuron
}

RONALD E. SOSEBEE, W.E. BOYD, AND C.S. BRUMLEY

\section{Abstract}

Broom snakeweed was effectively controlled for at least 3 years with $0.6 \mathrm{~kg}$ a.i./ha $(80 \%$ wettable powder) tebuthiuron on the Southern High Plains. Total herbage production decreased following broom snakeweed control, but grass yield generally increased when the snakeweed was removed. Broom snakeweed control was not affected by application time during the year. However, grass production was significantly reduced for three growing seasons by application of tebuthiuron in May. Grass yield was not affected by applications in either November or January.

Broom snakeweed (Xanthocephalum sarothrae), also known as turpentine weed is a rangeland problem in the western United States. It also occurs in much of Mexico. This halfshrub occurs on disturbed areas (Schmutz et al. 1959; Costello 1944) and overgrazed ranges (Campbell and Bomberger 1934; Gardner 1951; Jaradine and Forsling 1922). However, it is highly cyclic and not considered a reliable indicator of overgrazing (Vallentine 1971; Dahl et al. 1976).

Broom snakeweed competes with grasses for nutrients and water. Young seedlings develop a deep taproot during the first growing season and may extract water from greater depths than grasses (Ragsdale 1969). Ueckert (1979) reported that complete removal of boom snakeweed significantly increased perennial shortgrass production. Similarly, production of big bluestem (Andropogon gerardi) was decreased $12.4 \%$ by competition from rhizomatous and tap-rooted forbs, including broom snakeweed (Dwyer 1958).

Broom snakeweed produces saponin, a noncardioactive steroid glycoside that renders the plant toxic to livestock when grazed under certain conditions (Dollahite and Anthony 1957; Dollahite and Allen 1959; Dollahite et al. 1962). It is most toxic during leaf formation (Kingsbury 1964). It causes abortions and inflicts substantial economic losses on ranchers, especially when cattle graze the plants growing on light-textured soils. Calf losses on sandy sites in eastern New Mexico annually average 3 to $4 \%$ from cattle grazing broom snakeweed, but frequently average up to $60 \%$ (Sperry et al. 1964; R. Henard personal communication).

Attempts to control broom snakeweed have largely been erratic and unsuccessful. However, picloram (4-amino-3,5,6 trichloropicolinic acid) applied at $0.6 \mathrm{~kg}$ a.e./ha effectively controlled broom snakeweed in Wyoming (Gesink et al. 1973)

\footnotetext{
Authors, at the time of the research, were associate professor, graduate research assistant, and research associate, Department of Range and Wildlife Management, Texas Tech University, Lubbock 79409.

This study is a contribution of the College of Agricultural Sciences, Texas Tech University No. T-9-190. Boyd is now research associate, Remote Sensing Center, Texas A\&M University, College Station 77843. Brumley is now plant science representative, Lilly Research I aboratories (Elanco Products Company), Lubbock, Texas 79410.

The authors gratefully acknowledge Dr. J.C. Banks and Lilly Research Laboratories for their contribution to this study. They also thank Mr. Robert Henard (county extension agent, Lea County, New Mexico), Mr. Charles Fields and Mr. Wilson Bilbrey (ranchers) for their cooperation in this study.

Manuscript received June 6, 1978.
}

and in Arizona (Schmutz and Little 1970). Sperry and Robinson (1963) concluded that application of either 2,4-D (2,4-dichlorophenoxy acetic acid) amine or ester (1.1 kg a.e./ha) for two consecutive years, with optimum environmental conditions for growth, was necessary to control broom snakeweed. Other methods of chemical control have been tested but have not produced consistent results. Fire has been used to successfully control broom snakeweed during certain periods of the year (Dwyer 1967).

This study was initiated to test the efficacy and longevity of broom snakeweed control with tebuthiuron (N-[5-(1, 1-dimethyl-ethyl)-1,3,4-thiadiazol-2-yl]-N, $\mathrm{N}^{\prime}$-dimethylurea) applied at different dates and at variable rates. This study was also designed to measure herbage response following control of broom snakeweed.

\section{Experimental Procedure}

In the fall of 1974 , research was initiated to control broom snakeweed. It was divided into two phases.

\section{Phase I}

This phase of the research was conducted on small plots $(6 \times 6 \mathrm{~m})$ on the Texas Tech University campus in Lubbock. The plots were located on a Sandy Loam range site characterized by an Amarillo fine sandy loam soil (an Alfisol). The soil is deep and moderately permeable. Important decreaser species on this site include blue grama (Bouteloua gracilis), sidcoats grama ( $B$. curtipendula), and Arizona cottontop (Digitaria californica). Important increasers include buffalograss (Buchloe dactyloides) and perennial three-awns (Aristida sp.).

The climate is semiarid to subhumid, warm, temperate and continental. The average precipitation ranges 43 to $63 \mathrm{~cm} /$ year and occurs chiefly April through October.

The experiment consisted of a completely random design with six treatments and three replications. Treatments consisted of tebuthiuron ( $80 \%$ a.i. wettable powder) applications of $0.0,0.1,0.3,0.6,1.1$, and $1.7 \mathrm{~kg}$ a.i./ha. Tebuthiuron was applied in November, 1974, and January and May, 1975. However, no plot was sprayed more than once. The herbicide was dispersed in water and applied with a backpack sprayer in which compressed $\mathrm{CO}_{2}$ was used to maintain a constant spraying pressure. Approximately $1,300 \mathrm{ml}$ total volume of aqueous solution were applied to each plot.

During the fall of 1975, 1976, and 1977, herbage yields were measured by clipping five $0.11-\mathrm{m}^{2}$ quadrats within each $6 \times 6-\mathrm{m}$ plot. The herbage was dried at $60^{\circ} \mathrm{C}$ for $72 \mathrm{hr}$ and weighed. Grazing was excluded from these plots for the duration of the study.

The data were analyzed by split plot analysis of variance; the means were separated by Duncan's new multiple range test.

\section{Phase II}

Tebuthiuron $(80 \%$ a.i. wettable powder) was applied to 0.04 -ha plots $(12 \times 34 \mathrm{~m})$ in Lea County, New Mexico, to test field applications for control of broom snakeweed. The plots were located on a Loamy range site about $3.2 \mathrm{~km}$ west of Bronco, Texas, and on a Sandy range site about $16 \mathrm{~km}$ east of Crossroads, New Mexico. 
Table 1. Grass, forb, and broom snakeweed production $(\mathrm{kg} / \mathrm{ha})$ on a Sandy Loam site on the Texas Tech University campus in 1975 , 1976 , and 1977 following application of six rates of tebuthiuron.

\begin{tabular}{|c|c|c|c|c|c|c|}
\hline \multirow[b]{2}{*}{ Year } & \multirow[b]{2}{*}{$\begin{array}{c}\text { Tebuthiuron rate } \\
\text { (kga.i./ha) }\end{array}$} & \multicolumn{4}{|c|}{$\begin{array}{l}\text { Herbage production } \\
(\mathrm{kg} / \mathrm{ha})\end{array}$} & \multirow[b]{2}{*}{$\begin{array}{l}\text { Broom snakeweed } \\
\text { composition }(\%)\end{array}$} \\
\hline & & Grass & Forbs & $\begin{array}{c}\text { Broom } \\
\text { snakeweed }\end{array}$ & Total & \\
\hline 1975 & $\begin{array}{l}0 \\
0.1 \\
0.3 \\
0.6 \\
1.1 \\
1.7\end{array}$ & $\begin{array}{l}1547 a^{2} \\
1185 a \\
1949 a \\
1783 a \\
1842 a \\
1738 a\end{array}$ & $\begin{array}{l}963 a \\
624 a b \\
510 a b \\
621 a b \\
294 b \\
184 b\end{array}$ & $\begin{array}{r}643 \mathrm{a} \\
524 \mathrm{a} \\
486 \mathrm{a} \\
523 \mathrm{a} \\
67 \mathrm{a} \\
22 \mathrm{a}\end{array}$ & $\begin{array}{l}3153^{3} \\
2333 \\
2945 \\
2927 \\
2203 \\
1944\end{array}$ & $\begin{array}{c}20^{3} \\
22 \\
16 \\
17 \\
3 \\
1\end{array}$ \\
\hline 1976 & $\begin{array}{l}0 \\
0.1 \\
0.3 \\
0.6 \\
1.1 \\
1.7\end{array}$ & $\begin{array}{l}587 a \\
647 a \\
558 a \\
750 a \\
959 a \\
959 a\end{array}$ & $\begin{array}{l}68 a \\
31 a \\
49 a \\
19 a \\
55 a \\
34 a\end{array}$ & $\begin{array}{l}705 \mathrm{a} \\
519 \mathrm{ab} \\
526 \mathrm{ab} \\
163 \mathrm{bc} \\
47 \mathrm{c} \\
77 \mathrm{c}\end{array}$ & $\begin{array}{r}1361 \\
1197 \\
1142 \\
932 \\
1061 \\
1070\end{array}$ & $\begin{array}{r}52 \\
47 \\
51 \\
19 \\
4 \\
8\end{array}$ \\
\hline 1977 & $\begin{array}{l}0 \\
0.1 \\
0.3 \\
0.6 \\
1.1 \\
1.7\end{array}$ & $\begin{array}{l}968 \mathrm{bc} \\
847 \mathrm{c} \\
859 \mathrm{c} \\
1166 \mathrm{abc} \\
1321 \mathrm{ab} \\
1411 \mathrm{a}\end{array}$ & $\begin{array}{r}196 a \\
62 a \\
123 a \\
95 a \\
108 a \\
87 a\end{array}$ & $\begin{array}{r}831 \mathrm{a} \\
1024 \mathrm{a} \\
774 \mathrm{a} \\
300 \mathrm{~b} \\
55 \mathrm{~b} \\
136 \mathrm{~b}\end{array}$ & $\begin{array}{l}1994 \\
1932 \\
1757 \\
1561 \\
1484 \\
1635\end{array}$ & $\begin{array}{r}46 \\
58 \\
48 \\
21 \\
4 \\
9\end{array}$ \\
\hline
\end{tabular}

Values are averages from three treatment dates: November, 1974, and January and May, 1975.

Means for either grass, iorbs, or broom snakeweed within a year followed by similar letters are not significantly different $(P<0.05)$.

Means for total production and broom snakeweed composition were not separated by statistical analysis.

The Loamy range site was characterized by a Portales loam (a Mollisol) that generally occurs in swales and around playa lakes (Turner et al. 1974). The soil is developed over caliche or other stronger calcareous materials and it is moderately permeable. The major decreaser species on this site were black grama (Bouteloua eriopoda), sideoats grama, and vine mesquite (Panicum obtusum). The major increaser species include blue grama, buffalograss, ring muhly (Muhlenbergia torreyi), and broom snakeweed. Even though broom snakewced is quite abundant, it has not caused abortions in livestock grazing on this site.

The Sandy site was characterized by a degraded Gomez fine sandy loam (an Inceptisol), which occurs on level areas and in depressions. The soil is well drained and permeability is moderate to moderately rapid. Major decreaser species on this site include black grama, sideoats grama, and little bluestem (Schizachyrium scoparium). Blue grama, mesa dropseed (Sporobolus flexuosus), and perennial threeawns are major increasers. Broom snakeweed is most often classified as an invader on this site. This site was reseeded in the late 1950's or early 1960's primarily to Caucasion bluestem (Bothriochloa caucasica). Establishment of a stand of introduced grasses was only moderately successful.

The climate of Lea County is semiarid and continental with warm summers and cool, dry winters (Turner et al. 1974). The average annual precipitation is about $39 \mathrm{~cm}$, with at least half of it occurring June through October.

The experiment consisted of a completely random design with six treatments and three replications. Tebuthiuron was applied at rates of $0.0,0.1,0.3,0.6,1.1$, and $1.7 \mathrm{~kg}$ a.i./ha in November, 1975, and January, March, and May, 1976. Tebuthiuron was dispersed in water and applied with a boom sprayer mounted on a farm tractor. A constant spraying pressure was maintained by using compressed $\mathrm{CO}_{2}$. Approximately 38 liters total volume of aqueous solution were applied to each plot. No plot was sprayed more than once.

Grazing was not excluded from these plots. Therefore, it was not possible to obtain herbage yields. However, broom snakeweed densities were determined in the fall of 1976 (Sandy site only) and in the fall of 1977 . Counts were made in eighteen $0.22-\mathrm{m}^{2}$ quadrats within cach plot.

The data were analyzed with a split analysis of variance and the means were separated with Duncan's new multiple range test.

\section{Results and Discussion}

\section{Phase I}

Broom snakeweed comprised 20 to $52 \%$ of the species composition (by weight) of the untreated plant community on the Texas Tech campus (Table 1). Application of tebuthiuron ( 0.6 to $1.7 \mathrm{~kg}$ a.i. $/ \mathrm{ha}$ ) substantially reduced broom snakeweed in the community; however, it had little effect when applied at 0.1 to $0.3 \mathrm{~kg}$ a.i. $/ \mathrm{ha}$.

Hcrbagc production on this site reflected the fluctuations in precipitation during the 3 years of the study (Table 1). Grass production, which consisted primarily $(>75 \% \mathrm{w} / \mathrm{w})$ of blue grama and buffalograss, was not significantly affected by any rate of tebuthiuron until the third growing season after application, at which time production increased. Broom snakeweed began to be significantly affected during the second growing

Table 2. Influence of application date on grass, forb, and broom snakeweed production (kg/ha) during the first, second, and third year postapplication of tebuthiuron.

\begin{tabular}{clccc}
\hline & & \multicolumn{3}{c}{$\begin{array}{c}\text { Herbage production } \\
(\mathrm{kg} / \mathrm{ha})\end{array}$} \\
\cline { 2 - 5 } $\begin{array}{c}\text { Harvest } \\
\text { Date }\end{array}$ & $\begin{array}{l}\text { Treatment } \\
\text { date }\end{array}$ & Grass & Forbs & $\begin{array}{c}\text { Broom } \\
\text { snakeweed }\end{array}$ \\
\hline 1975 & Nov, 1974 & $2036 \mathrm{a}^{2}$ & $817 \mathrm{a}$ & $223 \mathrm{~b}$ \\
& Jan, 1975 & $1863 \mathrm{a}$ & $535 \mathrm{~b}$ & $763 \mathrm{a}$ \\
& May, 1975 & $1123 \mathrm{~b}$ & $245 \mathrm{c}$ & $146 \mathrm{~b}$ \\
1976 & Nov, 1974 & $917 \mathrm{~b}$ & $67 \mathrm{a}$ & $441 \mathrm{a}$ \\
& Jan, 1975 & $826 \mathrm{bc}$ & $47 \mathrm{a}$ & $400 \mathrm{a}$ \\
& May, 1975 & $487 \mathrm{c}$ & $14 \mathrm{~b}$ & $177 \mathrm{a}$ \\
& Nov, 1974 & $1356 \mathrm{a}$ & $151 \mathrm{a}$ & $592 \mathrm{a}$ \\
& Jan, 1975 & $1134 \mathrm{ab}$ & $106 \mathrm{a}$ & $596 \mathrm{a}$ \\
& May, 1975 & $795 \mathrm{~b}$ & $79 \mathrm{a}$ & $373 \mathrm{a}$ \\
\hline
\end{tabular}

1 Values are averages from 6 rates tebuthiuron: $0.0,1.0,0.3,0.6,1.1$, and $1.7 \mathrm{~kg} \mathrm{a.i.} / \mathrm{ha}$. Means for either grass, torbs, or broom snakeweed followed by sinilar letters are not significantly different $(\%<0.05)$. 


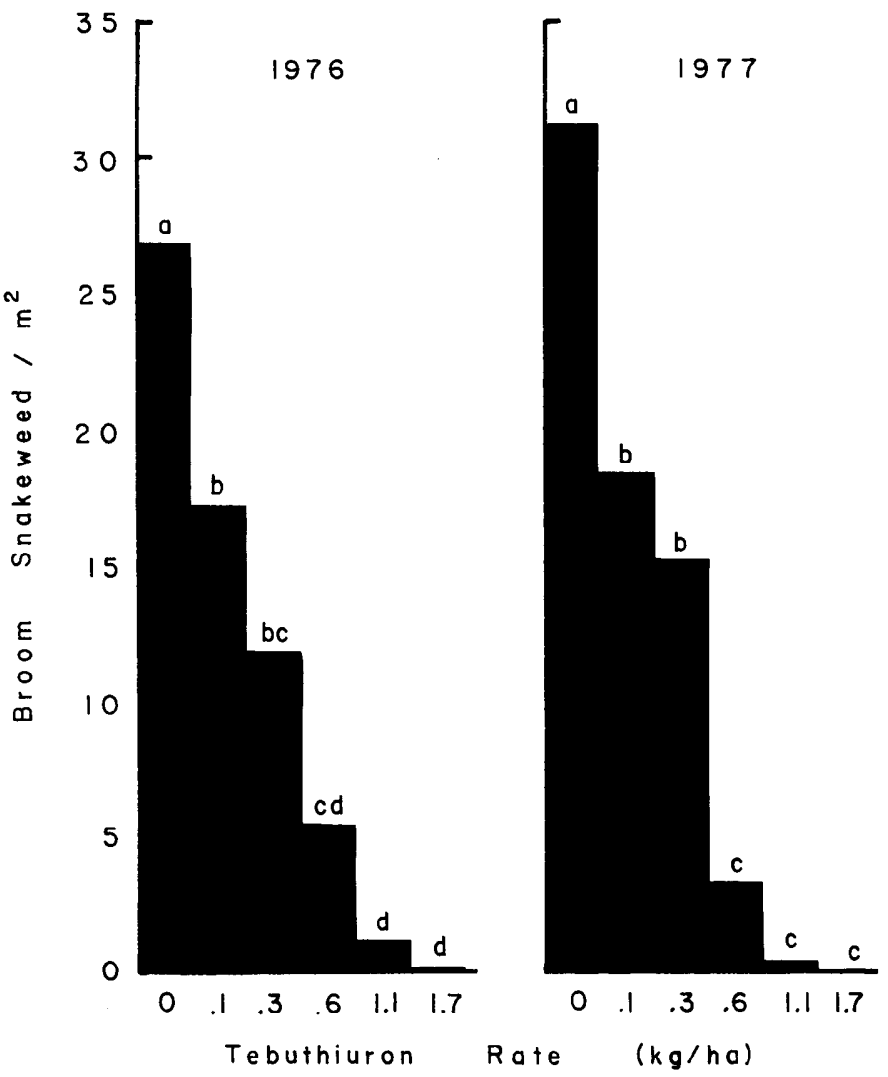

Fig. 1. Broom snakeweed densities (number $/ \mathrm{m}^{2}$ ) in 1976 and 1977 resulting from six treatments of tebuthiuron on a Sandy site in eastern New Mexico. Means within each year with similar superscripts are not significantly different $(\mathrm{P}<0.05)$.

season, whereas, forb production was significantly reduced the first growing season but not thereafter. Generally, as broom snakeweed was reduced, it was replaced by grass in the community. The total herbage yield was not increased by broom snakeweed removal, but the composition of the community improved.

The rate of tebuthiuron at which broom snakeweed began to be significantly reduced was $0.6 \mathrm{~kg}$ a.i./ha. Although differences in broom snakeweed yield resulting from different rates of tebuthiuron began to appear during the second growing season after application, the effects became more consistent during the third growing season. Reduction of broom snakeweed by tebuthiuron applied at $0.6 \mathrm{~kg}$ a.i./ha was not significantly different from applications of higher rates.

Time of year of tebuthiuron application generally did not affect broom snakeweed control, but it did significantly affect grass production (Table 2). Application of tebuthiuron in May, when most grass growth begins in the Southern High Plains, had a tendency to reduce grass production for at least three growing seasons. Grass production during the three growing seasons following tebuthiuron application was always greater from the treatments applied in November, 1974. Grass production from treatments applied in January, 1975, was intermediate. These data suggest that one should not apply tebuthiuron in the spring to control broom snakeweed, but rather in the fall or winter.

\section{Phase II}

Broom snakeweed growing on Loamy and Sandy range sites responded differently to tebuthiuron. Tebuthiuron at rates 0.1 to $1.7 \mathrm{~kg}$ a.i./ha significantly reduced the density of broom snake-

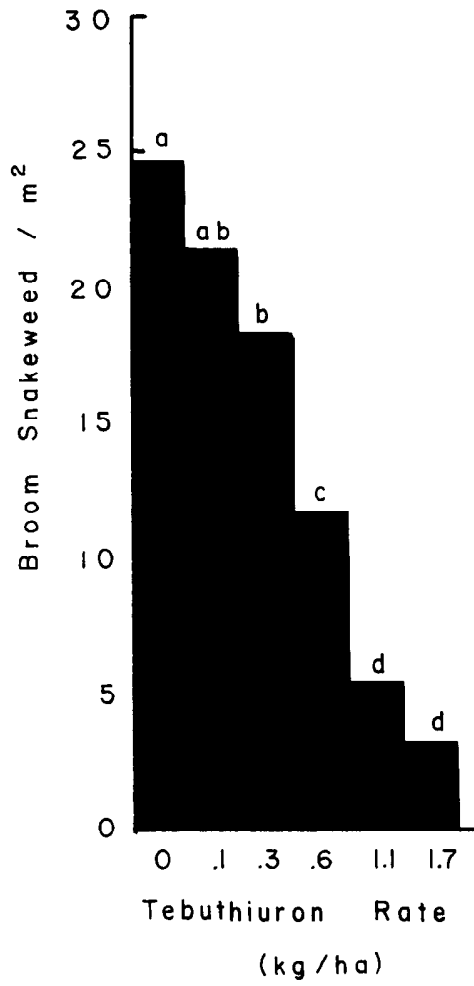

Fig. 2. Broom snakeweed densities (number $/ \mathrm{m}^{2}$ ) in 1977 resulting from sis treatments of tebuthiuron on a Loamy site in eastern New Mexico. Means with similar superscripts are not significantly different $(\mathrm{P}<0.05)$.

weed on the Sandy site at the end of the first growing seasor after application (Fig. 1).

Tebuthiuron applied at $0.6 \mathrm{~kg}$ a.i./ha significantly reduced broom snakeweed density on the Loamy site by the end of the second growing season after application (Fig. 2). Although the broom snakeweed density was reduced, the reduction was not as great as that on the Sandy site. Apparently, effectiveness of tebuthiuron is reduced by heavy textured soils. Tebuthiuron applied at 1.1 and $1.7 \mathrm{~kg} / \mathrm{ha}$ further reduced broom snakeweed density to approximately 5.4 and 3.2 plants $/ \mathrm{m}^{2}$, respectively, on the Loamy site.

\section{Management Implications}

Tebuthiuron has potential to control broom snakeweed on rangelands in the Southwest, especially on sandy soils. Results are best if tebuthiuron is applied preceding fall or winter precipitation. Application of tebuthiuron just prior to initiation of grass growth should be avoided because of injury to the grass during this phenological stage.

Ranchers and landowners should be aware that plant response to tebuthiuron can occur over at least a 3-year period. Perhaps the effectiveness of this herbicide will extend to 5 years or longer. Application of tebuthiuron at $0.6 \mathrm{~kg}$ a.i./ha reduces broom snakeweed on light-textured soils to an extent that releases competition and allows increased grass production. It is also important to note that livestock abortions average about $5 \%$ annually on Sandy sites dominated by broom snakeweed, but may be as great as $60 \%$ under certain environmental conditions. Significant reduction of broom snakeweed on Sandy sites could concomitantly increase calf crops in these areas.

\section{Literature Cited}

Campbell, R.S., and E.H. Bomberger. 1934. The occurrence of Guiter- 
rezia sarothrae on Bouteloua eriopoda ranges in southern New Mexico. Ecology 15:49-61.

Costello, D.F. 1944. Natural revegetation of abandoned plow land in the mixed prairie association of northeastern Colorado. Ecology 25:312-26.

Dahl, B.F., R.E. Sosebee, E.B. Fish, and J.P. Goen. 1976. Range plant and range ecosystem studies applicable to the Rio Puerco Area, New Mexico. Texas Tech Univ., Dep. Range and Wild. Manage. Final Rep. to the Bureau of Land Management. $174 \mathrm{p}$.

Dollahite, J.W., and T.J. Allen. 1959. Feeding perennial broomweed to cattle, swine, sheep, goats, rabbits, guinea pigs, and chickens. Texas Agr. Exp. Sta. Prog. Rep. 2105.6 p.

Dollahite, J.W., and W.V. Anthony. 1957. Experimental production of abortions, premature calves and retained placentas by feeding a species of perennial broomweed. Southwest Vet. 10:128-131.

Dollahite, J.W., T. Shaver, and B.J. Camp. 1962. Injected saponins as abortifacients. Amer. J. Vet. Res. 23:1261-1263.

Dwyer, D.D. 1958. Competition between forbs and grasses. J. Range Manage. 11:115-118.

Dwyer, D.D. 1967. Fertilization and burning of blue grama grass. J. Animal Sci. 26:934.

Gardner, J.L. 1951. Vegetation of the creosote area. Ecol. Monogr. 21:379403.

Gesink, R.W., H.P. Alley, and G.A. Lee. 1973. Vegetation response to chemical control of broom snakeweed on a blue grama range. J. Range Manage. 26:139-143.
Jardine, J.T., and C.L. Forsling. 1922. Range and cattle management during drought. U.S. Dep. Agr. Bull. No. 1031. 83 p.

Kingsbury, J.M. 1964. Poisonous Plants of the United States and Canada. Prentice Hall. Englewood Cliffs, New Jersey. 625 p.

Ragsdale, B.J. 1969. Ecological and phenological characteristics of perennial broomweed. PhD Diss., Texas A\&M Univ., College Station. 135 p.

Schmutz, E.M., and D.E. Little. 1970. Effects of 2,4,5-T and picloram on broom snakeweed in Arizona. J. Range Manage. 23:354-357.

Schmutz, E.M., D.R. Cable, and J.J. Werwick. 1959. Effect of shrub removal on the vegetation of a semi-desert grass-shrub range. J. Range Manage. 12:34-37.

Sperry, O.E., and E.D. Robinson. 1963. Chemical control of perennial broomweed. Texas Agr. Exp. Sta. Prog. Rep. 2273. 7 p.

Sperry, O.E., J.W. Dollahite, G.O. Hoffman, and B.J. Camp. 1964. Texas plants poisonous to livestock. Texas Agr. Exp. Sta. B-1028. 59 p.

Turner, M.T., D.N. Cox, B.C. Mickelson, A.J. Roath, and C.D. Wilson. 1974. Soil survey, Lea County, New Mexico. U.S. Dep. Agr., Soil Conserv. Serv. 89 p.

Ueckert, D.N. 1979. Broom snakeweed: effect on shortgrass forage production and soil water depletion. J. Range Manage. (In press).

Vallentine, J.F. 1971. Range Development and Improvements. Brigham Young Univ. Press, Provo, Utah. 516 p. 